\title{
A COMPARATIVE STUDY OF THERMAL PERFORMANCES OF THREE MUD DWELLING UNITS WITH COURTYARDS IN COMPOSITE CLIMATE
}

\author{
Janmejoy GUPTA a, Manjari CHAKRABORTY ${ }^{\mathrm{b}}$, Arnab PAUL ${ }^{c}$, Vamsi KORRAPATTI $^{\mathrm{d}}$ \\ a, cDepartment of Architecture BIT Mesra, Birla Institute of Technology Mesra Ranchi, Ranchi, \\ Jharkhand, RANCHI, 835215 India \\ b. dBIT Mesra Ranchi, RANCHI, 835215 India \\ E-mails: ajanmejoy71@gmail.com (correspondingauthor); ${ }^{b}$ profmanjari@gmail.com; \\ carnabpaul1009@gmail.com; dvamsi.korra@gmail.com
}

Received 14 January 2015; accepted 04 November 2015

\begin{abstract}
Jharkhand is a state in the eastern part of India. The tropic of Cancer (23 and a half degree north line) passes through Ranchi district in Jharkhand. Mud huts with burnt clay tiled roofs in Ranchi district in Jharkhand are an integral component of the state's vernacular architecture. They come in various shapes, with a number of them having a courtyard type of plan. In general, it has been stated that courtyard type dwelling units show better thermal performance during summer and winter. In this paper, three types of mud huts with courtyards are taken as a study and through temperature measurements in the south side rooms and "Ecotect-Autodesk" (Version 2011) software simulations, their thermal performance during the hotter and colder parts of the year are observed. Thereafter, based on the study, the thermally better performing dwelling types in summer and winter are identified among the three sub-types studied. It is found that all courtyard type dwellings do not necessarily show better thermal performance in summer and winter in composite climate. Certain recommendations with respect to increasing thermal comfort in general in courtyard type huts are made.
\end{abstract}

Keywords: mud huts, courtyard, thermal performance, temperature measurements, simulations.

\section{Introduction}

One of the distinct vernacular architectural styles that exist in Jharkhand is small mud huts. As per studies conducted by Cooper and Dawson (1998), these huts

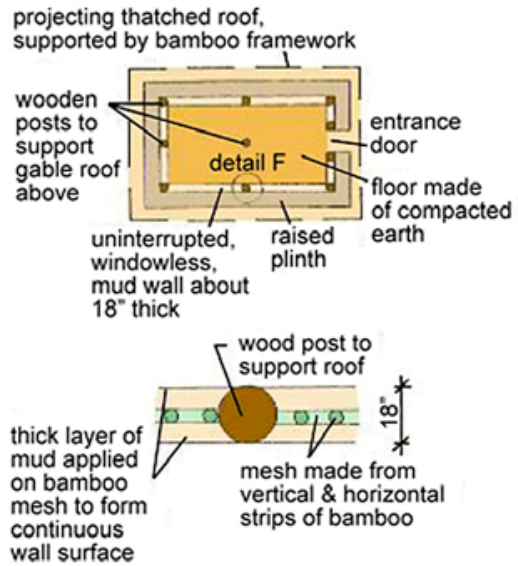

Fig. 1. Mud wall with wooden-post of typical hut - plan \& detail (Reproduced from Dhar 1992) are built of mud, sticks, grass and pebbles. The roofs are made of either thatch or burnt clay tiles. These houses were typically self-built by family members, sometimes aided by neighbours (see Figs 1 and 2).

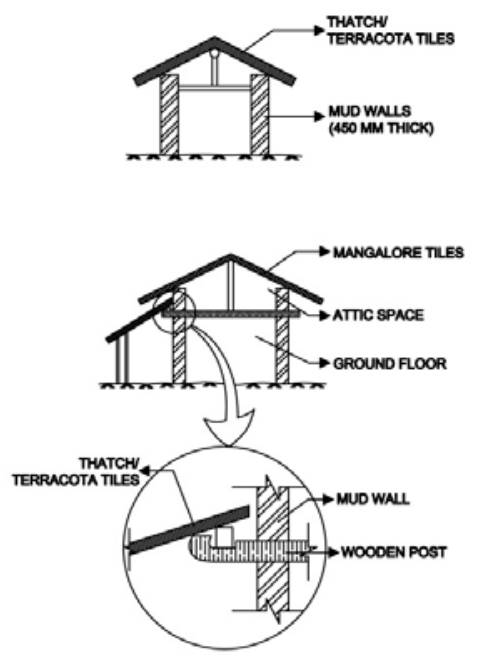

Fig. 2. Typical types of mud huts in studied area Source: sketched by author. 
As Gautam (2008) states, these huts are typically arranged in a linear pattern along the main street of a village, usually amidst a group of bamboo trees. The houses are normally surrounded by a fence made of bamboo, shrubs, or twigs that defined the boundary between the public street and the semi-private courtyard area. The open-to-sky courtyard acted as a prime space for the house, especially during the day in winter and in the evenings in summer. Most day to day activities occurred in this space. People commonly use the courtyard space to dry clothes and crops, alongside

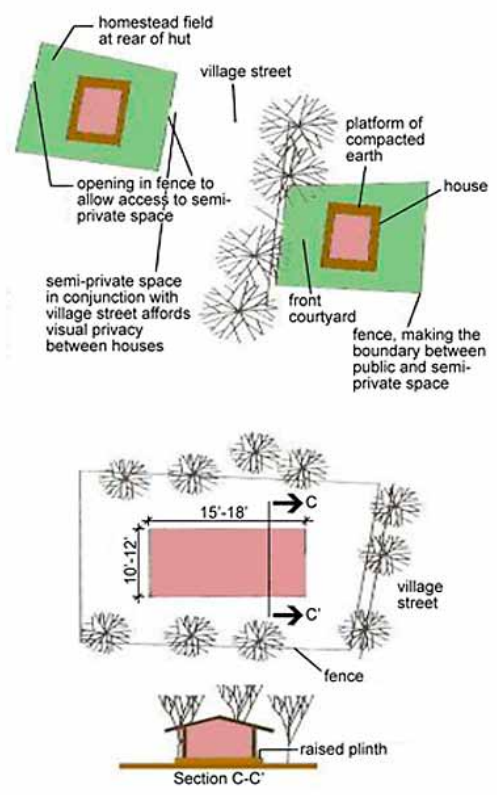

Fig. 3. Typical layout of huts in Jharkhand (Reproduced from Dhar 1992) using it for outdoor eating and washing utensils during day-time (Figs 3 and 4). Yannas (2001) defines a courtyard as a court or enclosed ground attached to a house, or a large paved or unpaved space surrounded by walls or building. A courtyard can be a roofless inner courtyard adjoining a house or an open-to-the-sky central courtyard. In studied examples, all courtyards are non-paved and open-to-sky.

In Jharkhand's vernacular mud huts, courtyards form an important component in a number of dwelling units. In the composite climate prevailing in Ranchi, (the study area, located in Jharkhand) courtyards are often used as an effective tool in thermally comfortable design. Bansal and Minke (1988) in their assessment of ideal design strategies in composite climate, for "Rural Housing in India", emphasise the courtyard as a buffer space and as a moderating influence on microclimate as shown in Table 1. Koenigsberger et al. (1997) and others have also suggested that the courtyard type dwelling units are a favourable solution in composite climatic regions for thermal comfort inside the dwellings.

Hassan Fathy (1973) built thick mud walls and traditional courtyards, in his works at New Gourna Village for 3,000 families, which supported cultural values. He created opportunities for passive cooling and enlisted the villagers as builders of their own homes (Figs 5 and 6). Fathy used the stack effect to good effect in his designed dwellings, with intelligently placed courtyards and proper openings at different levels. Yannas (2001) writes that in warm climates, outdoor spaces adjacent to buildings are as important as, and at times more important than, indoor spaces
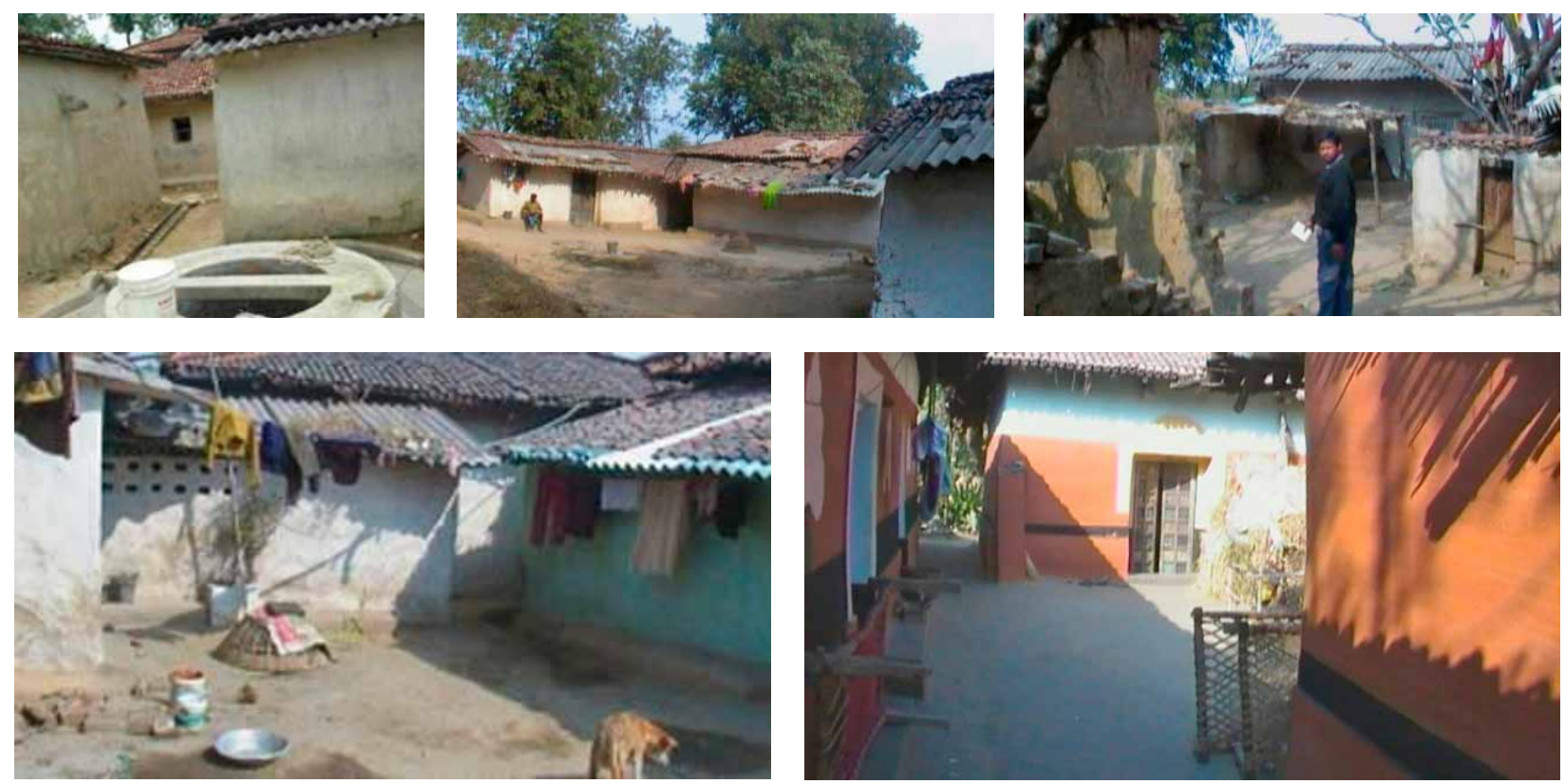

Fig. 4. Some dwelling units with courtyards in Ranchi's composite climate Source: photographs by author. 
Table 1. Study on traditional rural dwelling units in the composite climatic region

\begin{tabular}{cc}
\hline Reduction of solar heat gain & Ideal Design Strategy in Composite Climate \\
\hline Small perimeter-to-area ratio & Square plan, Low Wall Height \\
\hline Shading by neighbouring structures & Clustering of houses, Courtyard type planning \\
\hline Shading by vegetation & Deciduous trees \\
\hline Shading by overhangs & Shading by roof projection, sun-shades, fins \\
\hline Openings & Small openings \\
\hline
\end{tabular}

Source: Bansal and Minke (1988).

and should be provided with means of solar control and heat dissipation. Natural and man-made materials can be combined to provide shading and to cool surfaces and adjacent air.

Olgyay (1963) proposed a probable arrangement of dwellings in a slight variation of the already existing courtyard type planning as existing in Jharkhand to channelize cooling breezes in summer (see Fig. 7 below).

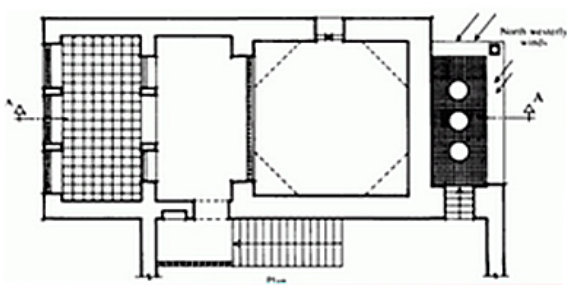

Fig. 5. Planning using traditional courtyards for proper ventilation by Hasan Fathy. Arrows indicate prevailing wind direction (Fathy 1973)

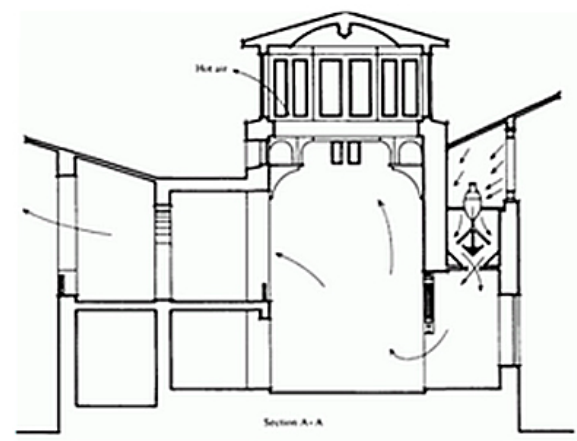

Fig. 6. Inducing stack effect through well designed courtyards and properly placed openings at different levels by Hasan Fathy Source: Fathy 1973

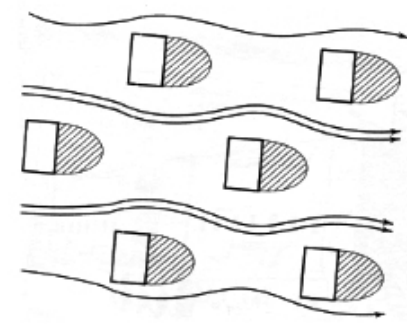

Fig. 7. Probable arrangement of huts in a slight variation of the already existing courtyard type planning to channelize cooling breezes in summer

Source: Olgyay 1963.
The literature review conducted above, throws light upon the different ways in which courtyards can be used in predominantly hot tropical and sub-tropical climates in creating thermal comfort. Their work has informed this research in the sense that the passive design strategies mentioned above and the ways of using the courtyard intelligently as a means of passive design intervention was learnt from these studies. That in turn, is the core focus of this research paper. The research discussed in this paper examines how the courtyard-type dwellings perform thermally in composite climatic area around Ranchi, especially in peak summer and peak winter season. This includes an analysis of the various sub-types of courtyard dwelling units present in the composite climatic region of Jharkhand and to what extent the courtyards do and might contribute to enhanced thermal comfort.

\section{Study area}

Jharkhand is a state located in the eastern part of India. It can be categorized into two types of climatic divisions, namely, the composite zone and the warm-humid climate, as denoted by the two colours on the map (see Fig. 8 below).

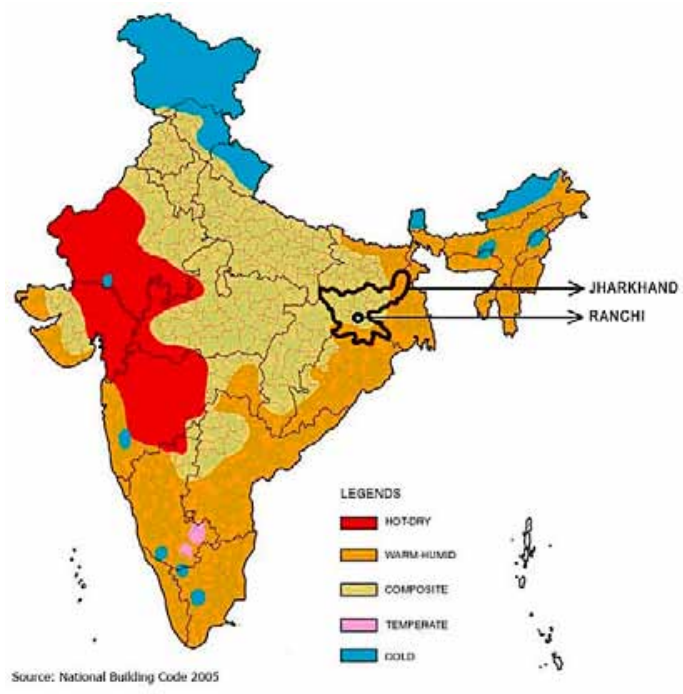

Fig. 8. Location of Ranchi in Composite climate region Source: SP 7:2005, National Building Code of India 2005. 


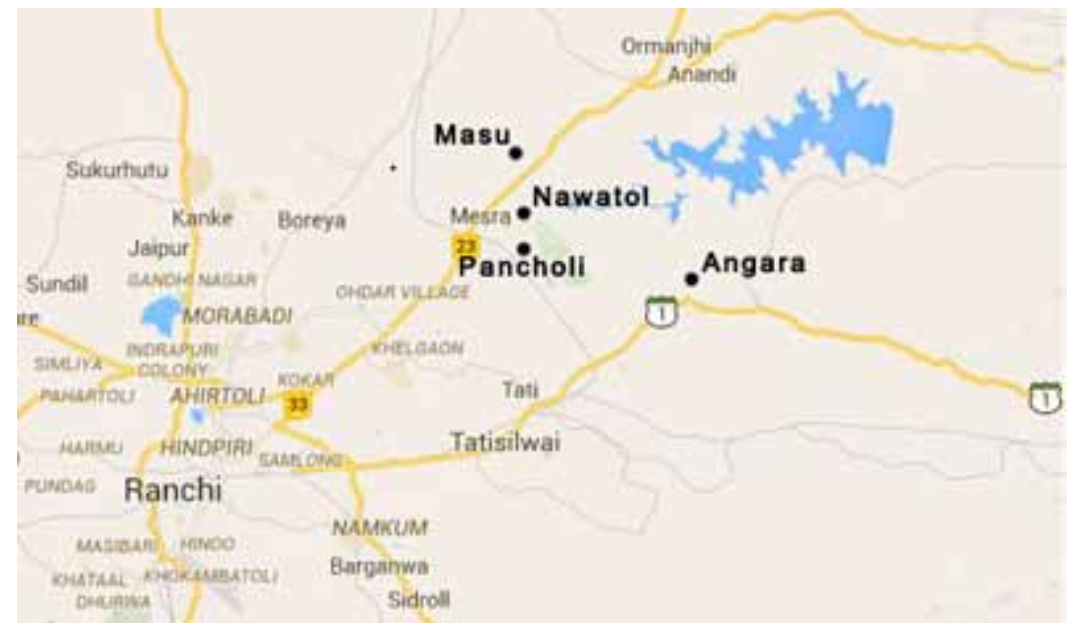

Fig. 9. Location of 4 study villages near Ranchi Source: Compare Infobase Ltd. 2014.

Table 2. Description of three sample huts

\begin{tabular}{|c|c|c|}
\hline SAMPLE HUT 1 & SAMPLE HUT 2 & SAMPLE HUT 3 \\
\hline $\mathrm{N}$ & $\mathrm{N}$ & $\widehat{\mathrm{N}}$ \\
\hline $\begin{array}{l}\text { Approx. Area }=128 \text { sq meters. } \\
12 \text { meters by } 12 \text { meters, with } \\
\text { central open courtyard measuring } \\
20 \text { sq meters. } \\
2 \text { voids on northern wall and } 2 \text { on } \\
\text { southern wall. } \\
\text { Note: A few internal Doors opening } \\
\text { towards courtyard are considered } \\
\text { as voids, other door openings } \\
\text { including main entrance door, not } \\
\text { considered as voids, as those doors } \\
\text { are usually kept closed. }\end{array}$ & $\begin{array}{c}\text { Approx. Area }=100 \text { sq. Meters. } \\
\text { Central Courtyard surrounded by } 4 \\
\text { square shaped rooms on four sides. } \\
\text { Each square unit measures } 5 \text { meters } \\
\text { by } 5 \text { meters. Central courtyard of } 25 \\
\text { square meters. } \\
3 \text { voids on northern walls and } 3 \text { voids } \\
\text { on southern walls, total } 6 \text { voids. } 3 \\
\text { voids on northern walls and } 3 \text { voids } \\
\text { on southern walls, total } 6 \text { voids. Doors } \\
\text { indicated as D1, D2, D3 \& D4. }\end{array}$ & $\begin{array}{l}\text { Approx. Area }=80 \text { sq. Meters. } \\
\text { One central rectangle measuring } 8 \\
\text { meters by } 4 \text { meters, flanked by two } \\
\text { rectangles on either side measuring } 8 \\
\text { meters by } 3 \text { meters. } \\
\text { Central Rectangular block has void in } \\
\text { north and door on south wall. The two } \\
\text { smaller blocks to the east and west have } \\
\text { voids on north and south walls. } 3 \text { voids } \\
\text { on northern wall and } 2 \text { voids on southern } \\
\text { wall. (plus the main entrance door, } \\
\text { indicated as D.) }\end{array}$ \\
\hline
\end{tabular}

As can be seen from map, the whole of Jharkhand, except a small portion of it to the south and east, falls within the composite zone of climate ${ }^{1}$. Ranchi, the capital of Jharkhand falls in the Composite climatic zone. The Tropic of Cancer ( $231 \frac{1}{2}$ degree North latitude)

\footnotetext{
1 Description of composite climate provided in next section, viz., Characteristics of Composite type climate.
}

passes through Ormanjhi, Ranchi District, very near to the study area. Angara, Nawatoli, Pancholi, and Masu, four villages within a 50 kilometre radius of Ranchi have been chosen as the Study area, in the composite climate region (see Fig. 9). Ranchi's geographical location is 23.38 degrees north latitude and 85.33 degrees east longitude. 

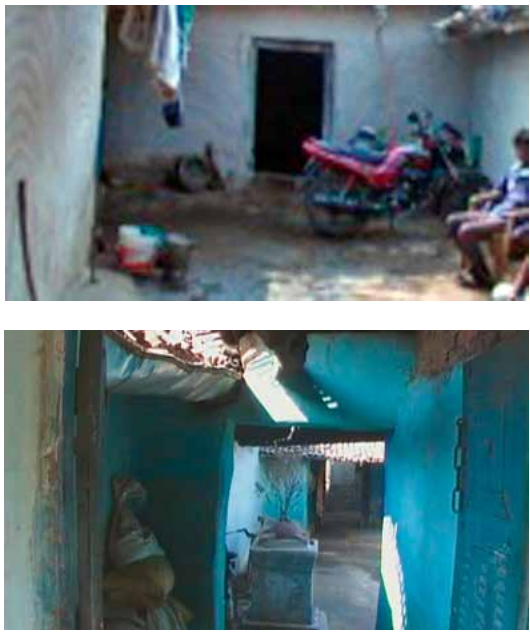

Fig. 10. Square with central open courtyard

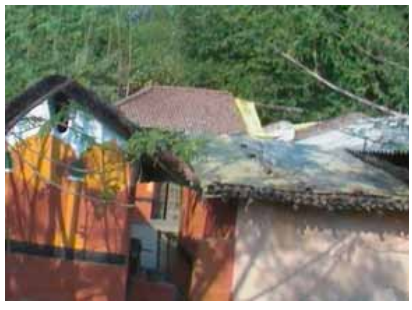

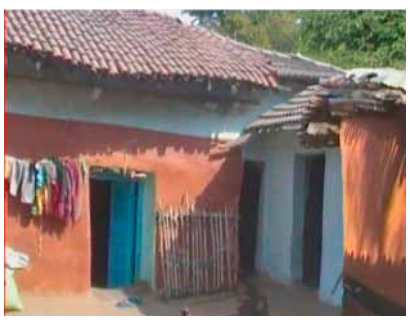

Fig. 11. Plus Shaped with central courtyard in the middle

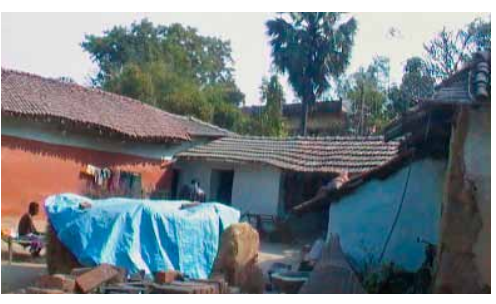

Fig. 12. U-shaped dwelling unit with south side open courtyard
The three types of dwelling units with courtyards which have been chosen for the study are shown below in Figures 10, 11 and 12. The three types that are explored in this research have similar floor areas, wall heights and internal volumes. The internal floor area for each design is close to 100 square metres and the floor to roof top height is approximately 4 metres. The walls are made of $450 \mathrm{~mm}$ thick mud walls and roof of burnt clay tiles. The sizes of the window-like openings are approximately 0.4 meters by 0.4 meters. All three of the dwelling units have window-like openings on both the north and south walls (see Table 2 below). All the three huts studied were stand-alone huts without much influence of neighbouring huts.

\section{Characteristics of composite type climate}

As per Koenigsberger et al. (1997) composite climates are neither consistently hot and dry, nor warm and humid. Their characteristics change from season to season, alternating between long hot, dry periods to shorter periods of concentrated rainfall and high humidity. In many areas there is also a third season, with dry sunny days and cold nights, which is referred to as winter.

The composite zone covers the central part of India. Some cities that experience this type of climate are New Delhi, Kanpur, Ranchi and Allahabad. A variable landscape and seasonal vegetation characterise this zone. The intensity of solar radiation is very high in summer with diffuse radiation amounting to a small fraction of the total. In monsoons, the solar intensity is low with predominantly diffuse radiation. The maximum daytime temperature in summers is in the range of $32-43{ }^{\circ} \mathrm{C}$, and night time values are from 27 to $32^{\circ} \mathrm{C}$.
In winter, the values are between 10 to $25^{\circ} \mathrm{C}$ during the day and 3 to $10^{\circ} \mathrm{C}$ at night.

The relative humidity is about $20-25 \%$ in dry periods and $55-95 \%$ in wet periods. The presence of high humidity during monsoon months is one of the reasons why a place like Ranchi is grouped under the composite and not hot and dry climate. Precipitation in this zone varies between 500-1300 mm per year. This region receives strong winds during monsoons from the south-east and dry cold winds from the north-east. In summer, the winds are hot and dusty. The sky is overcast and dull in the monsoon, clear in winter and frequently hazy in summer.

Generally, composite regions experience higher humidity levels during monsoons than hot and dry zones. Otherwise most of their characteristics are very similar. In studied case in Ranchi, the prevailing summer evening wind is from the southern side at average speeds of 0.5 to $1 \mathrm{~m} / \mathrm{second}$, rising up to a maximum of $2 \mathrm{~m} / \mathrm{second}$ occasionally and $3 \mathrm{~m} / \mathrm{second}$ on rare occasions.

\section{Research methodology: temperature/humidity measurements and software simulation using Ranchi climate file}

As discussed before, Fathy (1973), Koenigsberger et al. (1997), Bansal and Minke (1988), Yannas (2001) and others have suggested that the courtyard type dwelling units are a favourable solution in composite climatic regions for thermal comfort inside the dwellings. To what extent this statement might be true for the composite climatic area around Ranchi and under what conditions, is verified by carrying out detailed temperature measurements inside the various types of courtyard type huts found in Jharkhand in peak of summer and winter? 
To obtain an adequate building performance data several steps were taken, namely:

- Identify villages in composite climatic region nearby Ranchi.

- Identify different types of courtyard type dwellings in the identified villages.

- Carry out detailed temperature measurements in peak of summer and peak of winter and YearRound Relative Humidity measurements. Peak summer and peak winter identified by studying previous year's climatic records.

- Carry out Software simulation after digitally recreating three chosen sample units for calculating number of discomfort hours due to excess heat and excess cold through the year in each of the three dwelling units.

- Verify software simulation results through actual temperature measurement records.

- Identify extent of thermal comfort enjoyed inside sample dwelling units and in courtyard in summer and winter.

- Identify which amongst the studied dwellings show better thermal performance in summer and winter and ascertain the reasons for the same.

- Give broad level solutions for improving thermal comfort in courtyard type dwellings in Ranchi's composite climate.

Based on historical precedents, hourly internal and external temperatures were observed during a seven-day period in the hottest part of the year, for the three studied dwelling units. This data provided reasonable information about the performance of the three different dwelling units in extreme summer conditions. Similarly, hourly temperature observations were recorded for seven days during the coldest period of the year. The recorded temperatures enabled an analysis of the thermal comfort levels inside the sample dwellings. Additionally, hot period and cold period temperature data was collected simultaneously from the courtyard in each dwelling. Simulations for each dwelling were completed using the Autodesk Ecotect Software (Version 2011). The simulations included the climate file created for Ranchi in .EPW format, which included complete temperature, humidity, solar radiation, sunshine, prevailing wind speed in $\mathrm{m} / \mathrm{sec}$ including direction and rainfall values. The output data from the simulations was compared to the measured data from each dwelling. For calculating the number of discomfort hours due to excess heat and excess cold, it is assumed that people can open and close voids as per requirement. The $\mathrm{U}$ (Thermal Transmittance) values along with the respective thermal capacity values of $450 \mathrm{~mm}$ mud wall and $100 \mathrm{~mm}$ thick burnt clay-tile on bamboo rafters are entered into the Ecotect Simulation software for number of hours of thermal comfort calculations.

Autodesk Ecotect, sustainable design analysis software, is a comprehensive concept to detail sustainable building design tool. Ecotect Analysis offers a wide range of simulation and building analysis functionality that can analyse performance of existing buildings and new building designs. The adaptive comfort model, which applies to spaces where people can open and close windows or voids, (ASHRAE Standard 55-2004), was used to calculate the number of thermal discomfort hours. The standard assumes that occupants:

- Are engaged in sedentary activities, (like sitting, cooking or reading),

- Will adapt their clothing to the climate (0.5 to 1.0 clo)

- Thermal response will depend partially on outdoor conditions, and

- Will have a wider comfort range than in buildings with centralized HVAC.

\section{Comfort conditions considered: a discussion of mathematical thermal comfort model used for calculations}

Adaptive Comfort Model was used for calculating number of thermal discomfort hours as its criterion fitted the conditions existing in the huts, as the studied spaces where spaces where people could open and close windows or voids. Occupancy of four people was assumed in each sub-type of dwelling unit studied.

According to the default values programmed into the simulation software, following ASHRAE Standard $55-2004$, a range of $19.4^{\circ} \mathrm{C}\left(67^{\circ} \mathrm{F}\right)$ and $27.77^{\circ} \mathrm{C}\left(82^{\circ} \mathrm{F}\right)$ is ideal for thermal comfort. For calculating number of hours of discomfort hours due to excess heat or excess cold through software simulation, this range of temperatures are used as default values for maximum and minimum comfortable temperatures. Relative humidity of $25-70 \%$ is considered as optimum as per

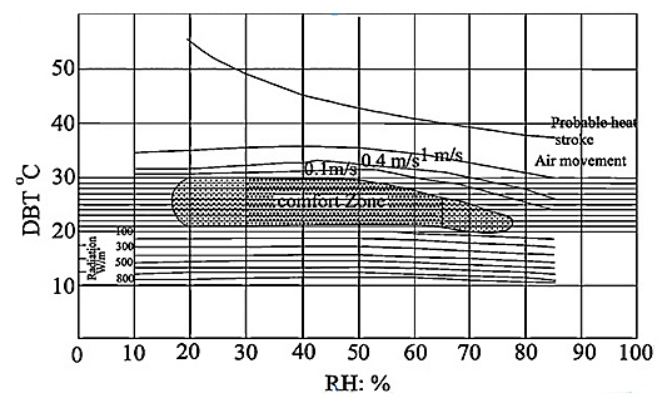

Fig. 13. Bio-climatic comfort chart for tropical climates by Olgyay showing upper and lower comfort limits Source: Koenigsberger et al. 1997. 


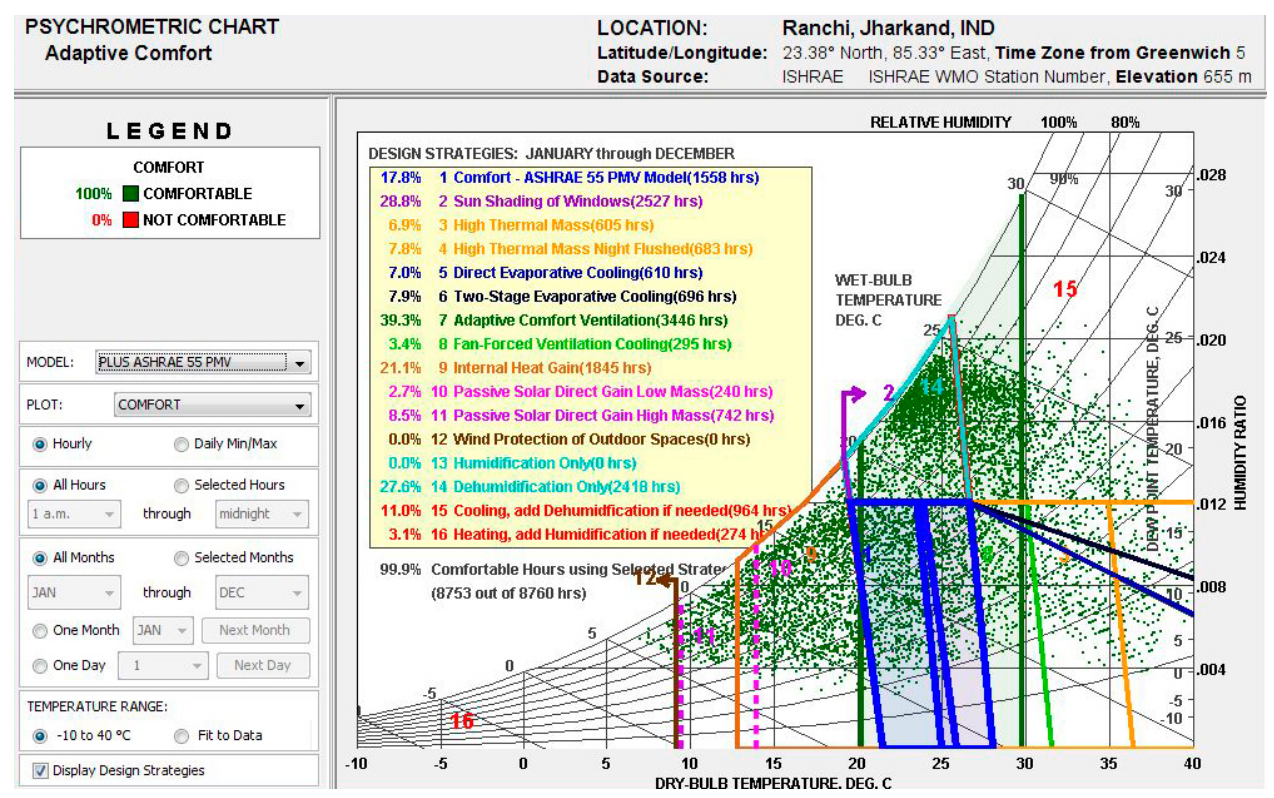

Fig. 14. Revised Building Bio-Climatic Comfort Chart (BBCC) for Ranchi, Jharkhand showing limits of thermal comforts as per Adaptive Comfort Model and how building design strategies cause adjustments in comfort zone Source: generated in Climate Consultant Software by author after uploading detailed climate file for Ranchi.

ASHRAE Standard 55-2004. Wind speeds in the range of $0.5 \mathrm{~m} / \mathrm{second}$ to $2 \mathrm{~m} / \mathrm{sec}$ are considered comfortable considering the high Dry Bulb Temperatures reached in summer in Ranchi. Please refer psychrometric chart of Ranchi and designated comfort zone as shown below (Figs 13 and 14).

\section{The influence of air velocity on thermal comfort}

As can be seen in above wind-charts (Fig. 15), the prevailing wind direction is from South side in summer and from North side in winter in Ranchi. In weather data summary for Ranchi, provided based on composite. EPW climate file for Ranchi (Table 3), the average monthly wind speeds are high in April, May, June, and July. Average wind speeds are lowest in October, November, and December. But nocturnal ventilative cooling does not happen to a considerable extent in these four months in which the wind speeds are high as the high recorded temperatures inside the huts at night prove. The high wind speeds in these four hot summer months are not utilised in the studied huts.

An air speed of $0.5 \mathrm{~m}$ per second equates to a 3 degree drop in temperature at relative humidity of 50 per cent (Reardon, Downton 2013). Night-time flushing out of heat is required for night time cooling. The recorded temperatures at nighttime inside the three studied huts in summer remain high although outside temperatures after mid night drop down till about 26-27 degree Celsius in the hottest period of the year. However, the temperatures inside the mud huts hover at around 35-37 degree Celsius, a good 8 to 10 degrees more. This can be attributed to the lack of adequate nocturnal ventilative cooling (see Fig. 17).

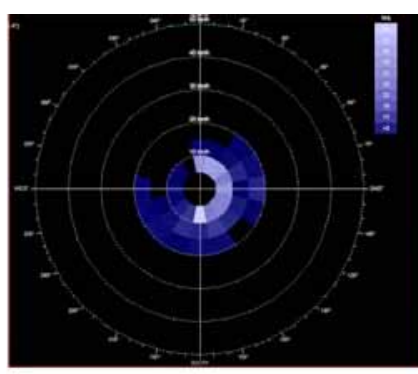

Summer Night

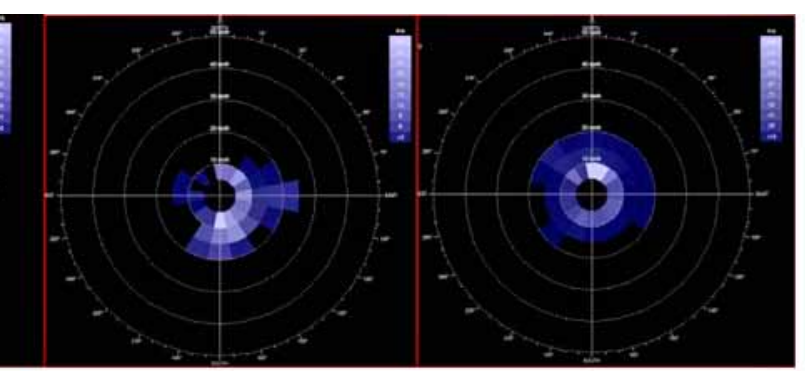

Summer

Evening Winter

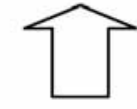

NORTH

Fig. 15. Prevailing wind direction: from South side in summer \& from North side in winter in Ranchi Note: white portions show predominant wind direction. 
Table 3. Average monthly wind speeds (in $\mathrm{m} / \mathrm{sec}$ ) in Ranchi

\begin{tabular}{|c|c|c|c|c|c|c|c|c|c|c|c|c|c|}
\hline \multicolumn{4}{|l|}{ WEATHER DATA SUMMARY } & \multicolumn{3}{|c|}{$\begin{array}{l}\text { LOCATION: } \\
\text { Latitude/Longitude: } \\
\text { Data Source: }\end{array}$} & \multicolumn{7}{|c|}{$\begin{array}{l}\text { Ranchi, Jharkand, IND } \\
23.38^{\circ} \text { North, } 85.33^{\circ} \text { East, Time Zone from Greenwich } 5 \\
\text { ISHRAE ISHRAE WMO Station Number, Elevation } 655 \mathrm{~m}\end{array}$} \\
\hline MONTHLY MEANS & JAN & FEB & MAR & APR & MAY & JUN & JUL & AUG & SEP & OCT & NOV & DEC & \\
\hline Global Horiz Radiation (Avg Hourly) & 444 & 559 & 558 & 649 & 639 & 546 & 471 & 414 & 412 & 463 & 436 & 385 & Wh/sq.m \\
\hline Direct Normal Radiation (Avg Hourly) & 531 & 670 & 504 & 672 & 581 & 397 & 239 & 159 & 200 & 338 & 448 & 433 & Wh/sq.m \\
\hline Diffuse Radiation (Avg Hourly) & 136 & 129 & 195 & 149 & 187 & 234 & 287 & 293 & 267 & 231 & 163 & 141 & Wh/sq.m \\
\hline Global Horiz Radiation (Max Hourly) & 871 & 1016 & 1012 & 1218 & 1224 & 1126 & 1066 & 883 & 895 & 879 & 802 & 757 & Wh/sq.m \\
\hline Direct Normal Radiation (Max Hourly) & 1196 & 1315 & 1200 & 1309 & 1238 & 1242 & 963 & 614 & 807 & 943 & 1088 & 1072 & Wh/sq.m \\
\hline Diffuse Radiation (Max Hourly) & 1196 & 1315 & 1200 & 1309 & 1238 & 1242 & 963 & 614 & 807 & 943 & 1088 & 1072 & Wh/sq.m \\
\hline Global Horiz Radiation (Avg Daily Total) & 4017 & 5149 & 5539 & 7188 & 7132 & 6109 & 5244 & 4579 & 4349 & 4333 & 4044 & 3506 & Wh/sq.m \\
\hline Direct Normal Radiation (Avg Daily Total) & 4803 & 6301 & 5093 & 7530 & 6627 & 4535 & 2704 & 1762 & 2160 & 3342 & 4345 & 3981 & Wh/sq.m \\
\hline Diffuse Radiation (Avg Daily Total) & 1246 & 1232 & 1971 & 1676 & 2117 & 2643 & 3202 & 3239 & 2819 & 2173 & 1524 & 1301 & Wh/sq.m \\
\hline Global Horiz Illumination (Avg Hourly) & 0 & 0 & 0 & 0 & 0 & 0 & 0 & 0 & 0 & 0 & 0 & 0 & lux \\
\hline Direct Normal Illumination (Avg Hourly) & 0 & 0 & 0 & 0 & 0 & 0 & 0 & 0 & 0 & 0 & 0 & 0 & lux \\
\hline Dry Bulb Temperature (Avg Monthly) & 16 & 19 & 24 & 28 & 29 & 28 & 26 & 25 & 25 & 23 & 20 & 17 & degrees $C$ \\
\hline Dew Point Temperature (Avg Monthly) & 7 & 7 & 14 & 12 & 17 & 20 & 22 & 23 & 21 & 17 & 12 & 10 & degrees $C$ \\
\hline Relative Humidity (Avg Monthly) & 57 & 49 & 59 & 42 & 53 & 68 & 81 & 88 & 82 & 71 & 63 & 69 & percent \\
\hline Wind Direction (Monthly Mode) & 320 & 320 & 320 & 320 & 140 & 230 & 230 & 90 & 320 & 0 & 0 & 320 & degrees \\
\hline Wind Speed (Avg Monthly) & 2 & 3 & 2 & 3 & 3 & 3 & 3 & 2 & 2 & 1 & 1 & 1 & $\mathrm{~m} / \mathrm{s}$ \\
\hline Ground Temperature (Avg Monthly of 3 Depths) & 19 & 18 & 19 & 19 & 22 & 24 & 26 & 27 & 27 & 26 & 23 & 21 & degrees $\mathrm{C}$ \\
\hline
\end{tabular}

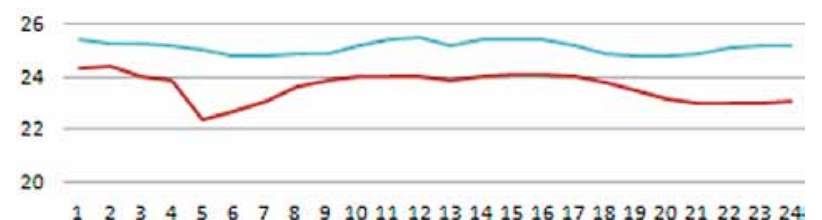

Fig. 16 . Hourly temperatures -27 th July

Note: blue graph: recorded temperatures inside the hut; and brown graph: temperatures recorded outside the hut on $27^{\text {th }}$ July.

The extent to which temperatures inside as well as outside the hut are reduced when the wind velocities are high are seen in the above temperature record taken on $27^{\text {th }}$ July, one of the windiest days of the year. The temperatures inside the hut (indicated in blue graph in Fig. 16 above) dip appreciably due to high wind velocities of more than 3 metre/second (Fig. 16).

\section{Comparison of Adaptive Comfort Model adopted in this case with other models of} thermal comfort fit for Indian sub-continent

As per Brager and De Dear (2001), proposed revisions to ASHRAE 55-2004, "Thermal Environmental Conditions for Human Occupancy", include a new adaptive comfort standard (ACS) that allows warmer indoor temperatures for naturally ventilated buildings during summer.

Subsequent research led to a proposal for an adaptive comfort standard (ACS) that would serve as an alternative to the PMV (Predicted Mean Value) -based method in ASHRAE Std. 55. The outdoor climatic environment for each building was characterized in terms of mean outdoor dry bulb temperature (DBT), i.e. To(DBT), instead of ET (Effective Temperature). Optimum comfort temperature, Tc (comfort temperature) was calculated as per formula given below:

$\mathrm{Tc}=0.31 \mathrm{To}(\mathrm{DBT})+17.8$ (in degree celsius)

Though metrics have been developed to quantitatively define thermal comfort, it is inherently subjective. As per Nicol (2001), Humphrey in 1981 derived a mathematical relationship between the optimum comfort temperature ( $\mathrm{Tc}$ ) and mean outdoor temperature (To) for a passive building: $\mathrm{Tc}=12.1+0.53$ To. He collected data from comfort surveys from all across the world and plotted the temperature reported as comfortable against outdoor temperatures for the month of survey. Nicol (2001), concluded after similar research in the Indian sub-continent that, $\mathrm{Tc}=17.0+$ 0.38 To. The difference between the two formulas is the subjective nature of thermal comfort. Nicol (2001) further states that Foss and Rohles (1982) had surmised that thermal comfort varies because of social conditions, acclimation to geographic locations, and culture. Thermally comfortable buildings respond to these variables to create comfortable conditions for users. Passively thermally comfortable buildings use different strategies to create such conditions. In this case it has been examined whether courtyards in dwellings can be such a strategy. 
Maximum and minimum comfort temperatures in Ranchi's climatic conditions: comparison between Adaptive Comfort Model and Brager/ De Dear and Nicol's methods for Indian conditions

The average maximum temperature recorded in Ranchi over the 7 day period in peak summer is 41 degree Celsius and average minimum temperature recorded in this period is 26 degree Celsius. Putting these values in Nicol's equation, maximum and minimum comfort temperatures for peak of summer are 32 degree Celsius and 27 degree Celsius respectively. For peak of winter, the comfort temperatures (maximum and minimum) based on measured outside temperatures work out to be 24.2 degree Celsius and 18.9 degree Celsius. The minimum comfort temperature values as per Nicol (18.9 degree Celsius) are almost at par with the Adaptive Comfort Model minimum comfort temperature value of 19.4 degree Celsius. However, the upper limit of thermal comfort as per Nicol (32 degree Celsius) is more than that laid down by the Adaptive Comfort Model (28 degree Celsius). Optimum comfort temperature, Tc (comfort temperature), calculated as per Brager and De Dear's new adaptive comfort standard (ACS) that allows warmer indoor temperatures for naturally ventilated buildings during summer come to about 18.4 degree Celsius to 30.94 degree Celsius based on outside Dry Bulb Temperatures measured through the year. Here too the maximum acceptable temperature for comfort is higher for the Adaptive comfort standard (30.94 degree Celsius) as compared to the Adaptive Comfort Model (28 degree Celsius), considered for comfort hour calculations in this case.

This suggests that number of discomfort hours due to excess heat calculated as per Ecotect (V 2011) simulations in this research following Adaptive Comfort Model would have been lesser had the comfort temperatures being calculated as per Nicol's and Brager/ De Dear's formulae.

\section{Location of temperature sensors}

To allow the analysis of daily variations within each dwelling and courtyard, data loggers were used to measure and acquire hourly temperature data. The data loggers were installed in the centre of the room at a height of $1.0 \mathrm{~m}$. The height of $1.0 \mathrm{~m}$ is based on the average human height while sitting (Das 2006). All data were automatically sampled at an interval of one hour (60 minutes). A digital thermometer was used to measure outdoor temperatures. All temperat- ures measured inside the three dwellings were taken from the rooms on the south side. Temperatures in the courtyards were measured by installing the data loggers in the centre of the courtyard at a height of 1.0 metres.

\section{Measured temperature data}

The graph given below (Fig. 17) shows the recorded average temperatures through a week in the hottest period of the year from $29^{\text {th }}$ May to $4^{\text {th }}$ June. The three different coloured graphs indicate the recorded temperatures of the three sample huts. The blue graph shows the variation of the outside average temperatures during the same period. Sample Hut 1 (square with central open courtyard) records the highest temperature amongst the three dwellings in summer. The lowest temperature in summer is recorded in Sample Hut 3 (U shaped dwelling). In winter too, Sample Hut 1 records the highest temperature. Sample Huts 1 (square with central open courtyard) and 2 (plus shaped dwelling with central square courtyard) are not ideal for summer-time inhabitation. But Sample Hut 1 shows better winter time performance than Huts 2 and 3 , recording up to 2 degree Celsius higher temperature than samples 2 and 3 (Fig. 18). Sample Hut 3 offers the best thermal comfort inside amongst the three huts in summer (Fig. 17).

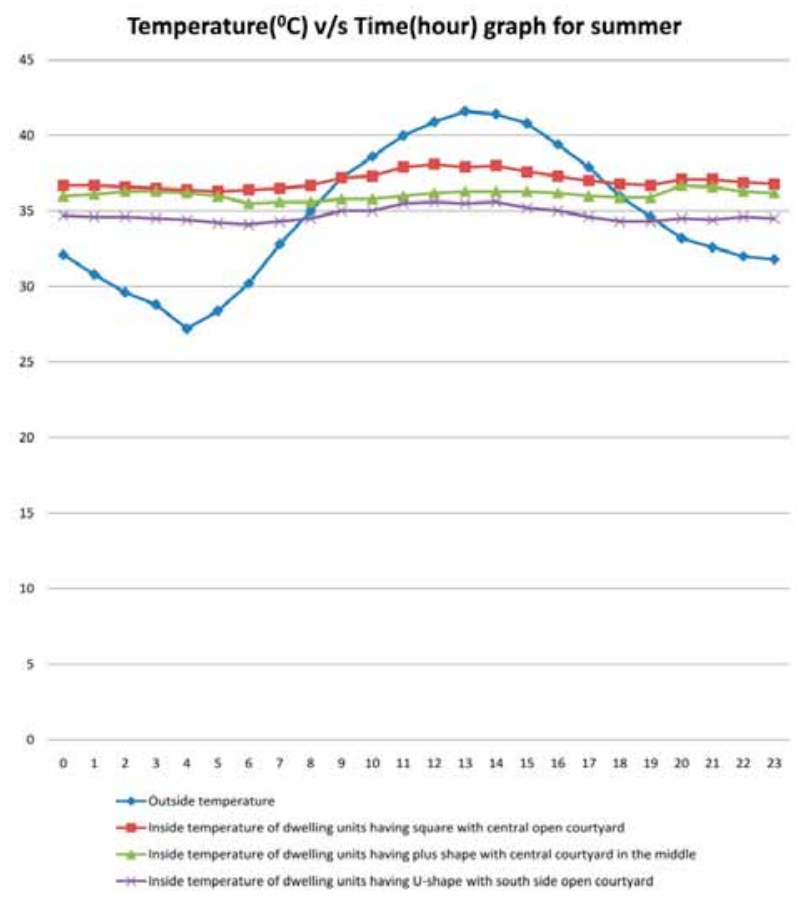

Fig. 17. Recorded average temperatures in week from $29^{\text {th }}$ May to $4^{\text {th }}$ June during hottest period of year 


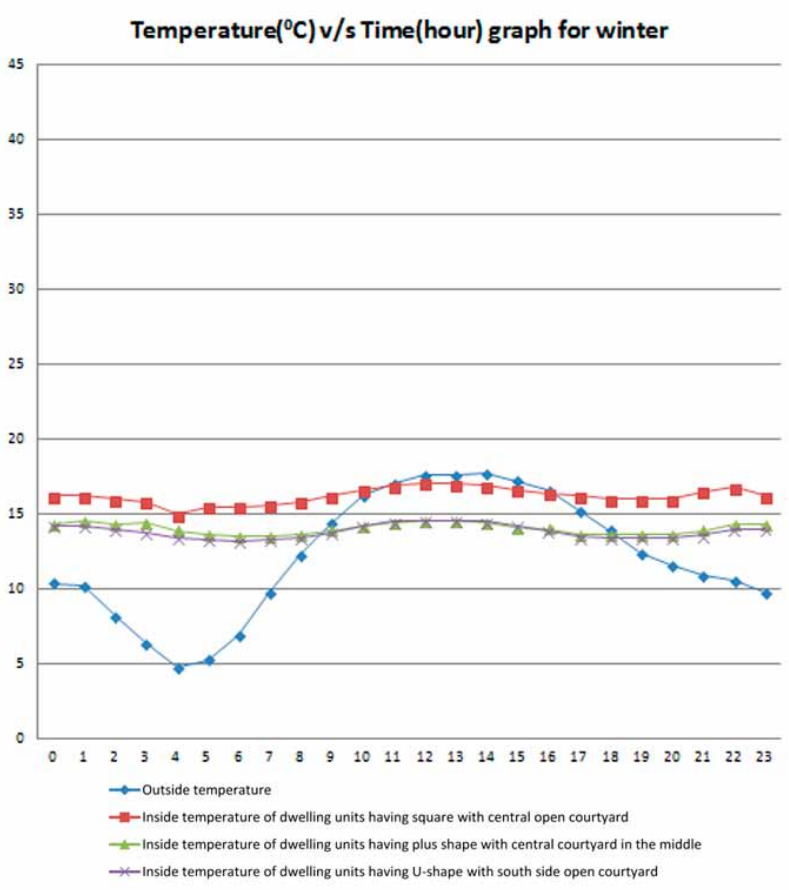

Fig. 18. Recorded average temperatures in week from $29^{\text {th }}$ December to $4^{\text {th }}$ January during coldest period of the year respectively

\section{Temperatures of courtyards for the three sample dwelling units}

The thermal performance of the courtyards on the basis of temperature measurements taken in the courtyard is discussed in this section. It is very hot in the courtyard from around $8 \mathrm{AM}$ in the morning to $5 \mathrm{PM}$ in the evening in summer, making it highly unusable in that period in peak summer in case of all the three dwellings (Fig. 19).

In winter the reverse is true and from $9 \mathrm{AM}$ in the morning till about $4 \mathrm{PM}$ in the evening the courtyard can be used extensively for various activities as it is actually done in practice (Fig. 20).

In the U Shaped dwelling unit with south side courtyard the courtyard temperatures in peak summer during afternoon becomes unbearably high due to the courtyard bearing the brunt of the summertime southern sunrays (Fig. 19).

\section{Recorded humidity values}

Humidity levels inside the mud hut are highest at night (increasing after 6:00 PM in the evening till about 7:30 AM the next morning) (Fig. 21).

July, August and September remain high humidity months, with both maximum and minimum humidity recorded being very high. (Fig. 21 and Fig. 22) These recorded humidity-levels have been used in the calculation of number of hours of thermal discomfort due to excess heat and excess cold as shown in Table 4 later.
Peak summer day

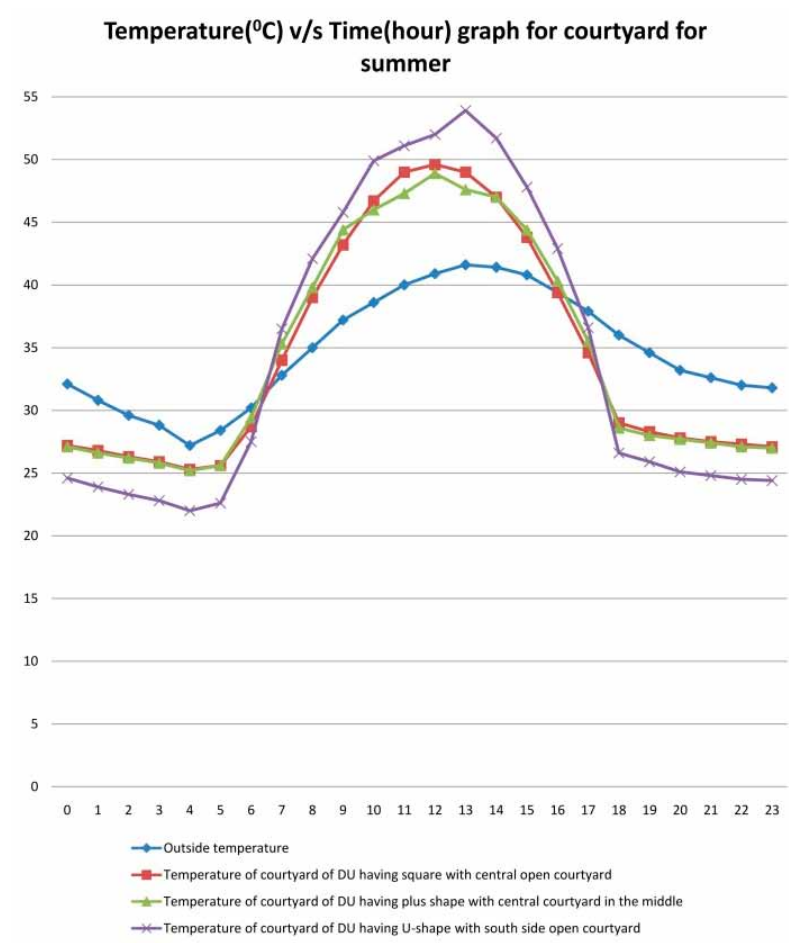

Fig. 19. Temperatures over a 24 hour period in the courtyard on $29^{\text {th }}$ May, in all the three dwellings, summer day

\section{Peak winter day}

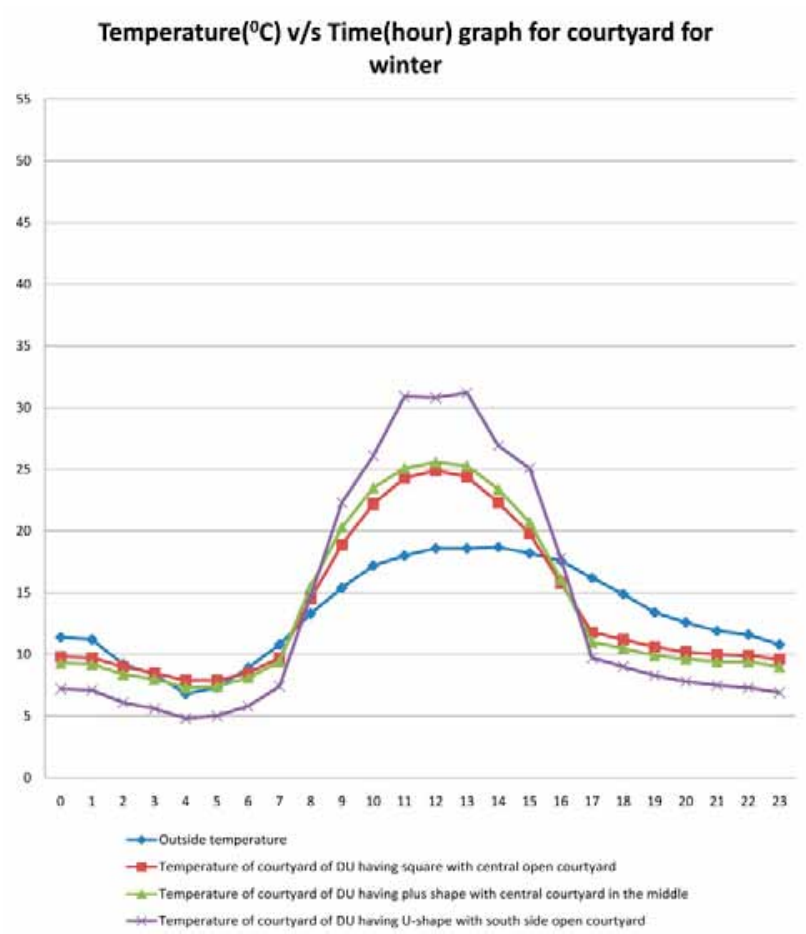

Fig. 20. Temperatures over a 24 hour period in the courtyard on $4^{\text {th }}$ January, in all the three dwellings, peak winter day 


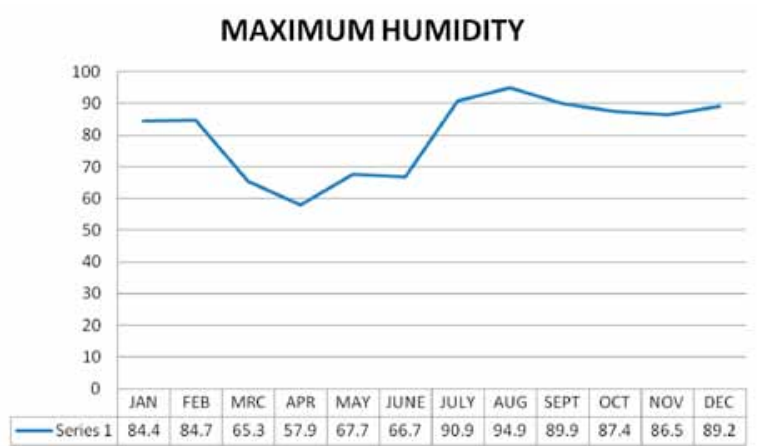

Fig. 21. Maximum humidity recorded throughout the year (At $7 \mathrm{AM}$ in the morning)

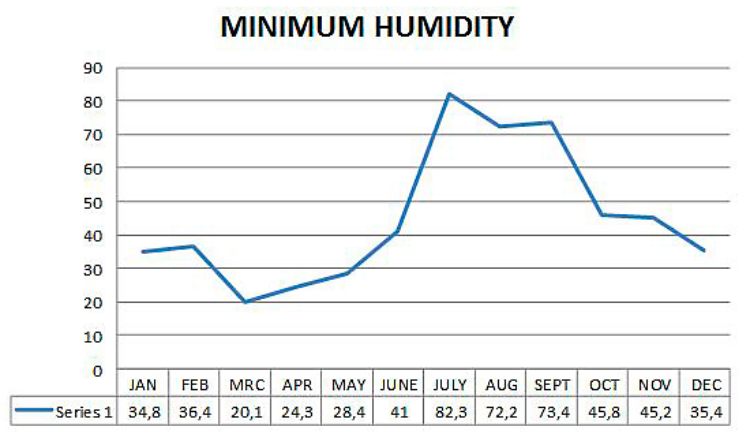

Fig. 22. Minimum humidity recorded through the year at 2 PM in the afternoon

Table 4. Detailed number of discomfort hours through the day (summer and winter) for the three dwellings

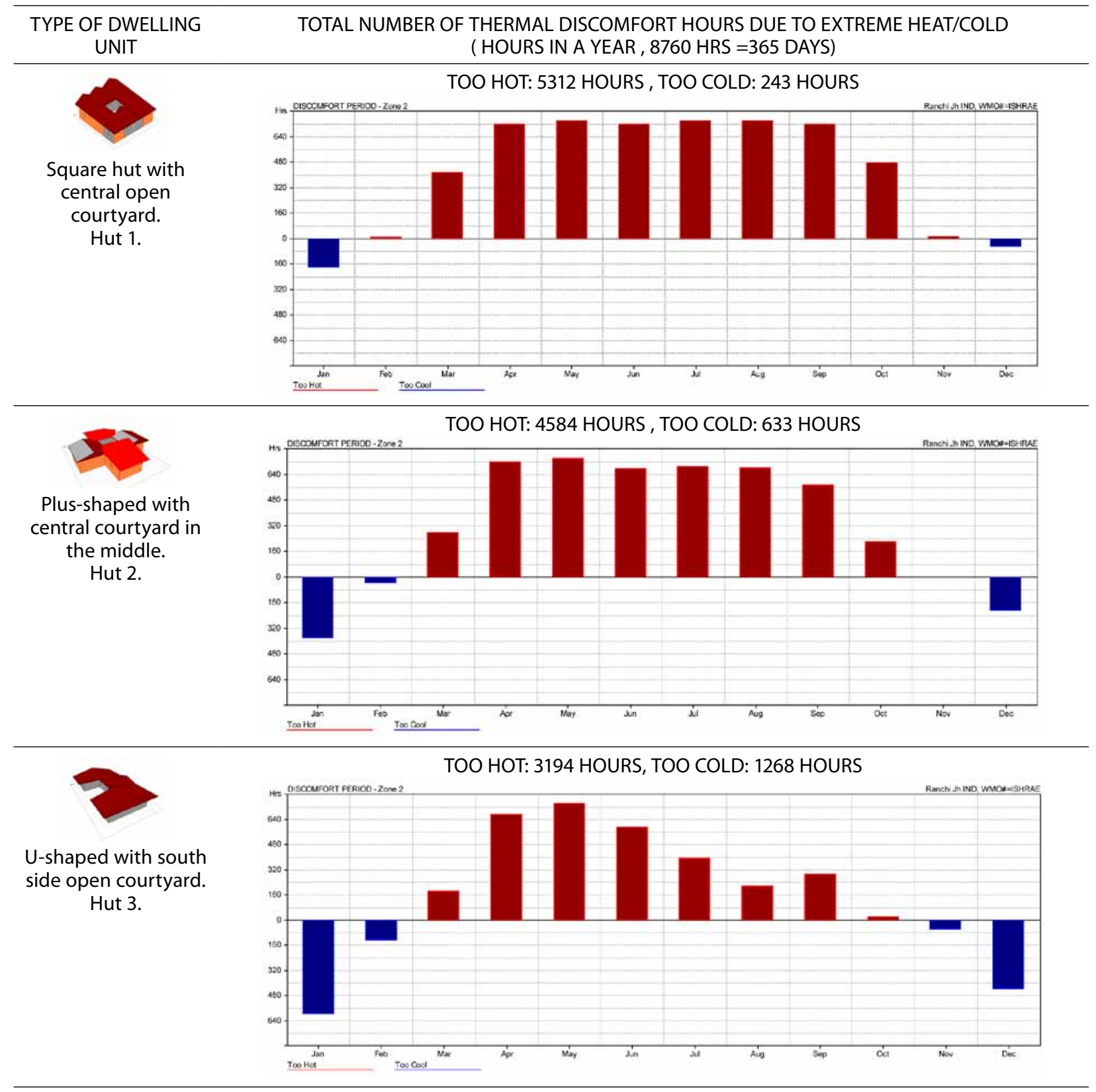




\section{Simulated data: calculation of total number of discomfort hours}

In generating the climate file for Ranchi, Relative Humidity values are also inputted in alongside the other climatic parameters that include temperature, humidity, solar radiation, sunshine, wind: prevailing wind speed in $\mathrm{m} / \mathrm{sec}$ and direction and Rainfall: (monthly total in $\mathrm{mm}$ ). The raw weather data from the meteorological station are usually analysed and presented in tabular form and/or in graph form. Some design handbooks and standards such as ASHRAE/ ISHRAE also provide general climatic data for building design and manual load calculations. To study year-round building performance, annual weather data will be required. The development of detailed computerized simulation programs for the thermal response of buildings has determined the need to generate a coherent set of data set to represent hourly yearly data. Most data systems construct a composite year's data by selecting periods from actual data over many years of recording. This data has different names: EPW in the United States and India, for example. In this case for generating the simulations the .EPW file for Ranchi has been used which includes air velocity, humidity data and et al.

The total number of discomfort hours due to excessive heat is greatest in Sample Hut 1, i.e. square dwelling unit with central courtyard, followed by Sample Hut 2, i.e. the plus shaped hut with central courtyard, and the least discomfort due to excess heat is present in Sample Hut 3, i.e. U-shaped dwelling unit (see Table 4 below). The opposite happens in winter, when the sample Hut 1 shows the least number of discomfort hours due to excess cold, followed by Sample Hut 2 and finally Sample hut 3 which has the most number of discomfort hours due to excess cold (see Table 4 below). From a summer-time point of view, the U-shaped dwelling unit with south-side open courtyard (sample Hut 3) exhibits least number of discomfort hours due to excess heat. Summer-time discomfort is prevalent in greater degree mainly in the months of April, May and June, with winter time discomfort being sizeable in January and December (see Table 4), (Sample Hut 3).

\section{Comparison between simulation results and measured temperature}

The temperature records plotted graphically for the hottest and coldest weeks of the year tally with the simulation results of total number of discomfort hours for peak summer and winter (Figs 17, 18 and Table 4). For example, the total number of discomfort hours due to excess heat as per simulation results is highest, for the square dwelling unit with central open courtyard (Sample Hut 1). The recorded temperatures for the same dwelling in the hottest period of the year are also highest, at nearly 3 degrees more than the recorded temperatures of the dwelling unit having U-shape with south side open courtyard (Fig. 17). Again, the total number of discomfort hours due to excess cold is minimum for Sample Hut 1 as per simulation results, and the temperatures recorded in the coldest part of the year for Sample Hut 1 is more than that recorded for the other two dwelling units (Fig. 18). The simulation results are thus verified by actual temperature measurements.

\section{Comparative analysis between the three sub-types of courtyard dwellings}

A comparison of the temperatures recorded at $6 \mathrm{AM}$ (early morning), 12 Noon, 6 PM (evening) and 12 Midnight for the three dwelling units on $29^{\text {th }}$ May, during the hottest period of the year, and $4^{\text {th }}$ January, during the coldest period of the year, is as follows: (all temperatures are in degree Celsius)

Table 5. Temperature measurements inside different types of courtyard dwelling units selected for detailed study at different times of the day and night on 29th May in hottest week of the year

\begin{tabular}{|c|c|c|c|c|c|}
\hline Dwelling Unit & Time & $6 \mathrm{AM}$ & $12 \mathrm{NOON}$ & $6 \mathrm{PM}$ & 12 MIDNIGHT \\
\hline & & 36.4 & 38.1 & 36.8 & 36.7 \\
\hline & & 35.5 & 36.2 & 35.9 & 36.0 \\
\hline & & 34.1 & 35.6 & 34.3 & 34.7 \\
\hline
\end{tabular}


Table 6. Temperature measurements inside different types of courtyard dwelling units selected for detailed study at different times of the day and night on $4^{\text {th }}$ January in the coldest week of the year

\begin{tabular}{|c|c|c|c|c|c|}
\hline Dwelling Unit & Time & $6 \mathrm{AM}$ & 12 NOON & 6 PM & 12 MIDNIGHT \\
\hline & & 16.5 & 18.1 & 16.9 & 17.2 \\
\hline & & 14.5 & 15.5 & 14.6 & 15.3 \\
\hline & & 14.2 & 15.6 & 14.4 & 15.2 \\
\hline
\end{tabular}

The temperatures at $6 \mathrm{AM}$ (morning), 12 Noon (Midday), 6 PM (evening) and 12 Midnight is highest for the square unit with central courtyard blocked from all sides (Sample Hut 1). It shows the worst thermal performance amongst the three sample huts in summer. On the other hand, on a peak winter day, the temperature recorded inside Sample hut 1 is 2 degree Celsius more than the temperatures recorded in the other two dwelling units. It shows the best thermal performance amongst the three in winter (Tables 5-6).

\section{Discussion}

Based on the above study, it can be surmised that Courtyard style dwelling units, though recommended as solutions for a composite climate, need to be properly designed, clustered and oriented to make them beneficial in reducing thermal discomfort during summer and lowering summertime temperatures through ventilation, as U-shaped dwelling unit with open courtyard shows. Much depends, as Szokolay (2004) had concluded, on how the courtyard is treated. An un-shaded courtyard like the ones studied, without water, can be a liability, warmer than the external environment, not only in winter, but also during the hottest period. Such unwanted heating has been recorded in courtyards as has been in this case too. The traditional courtyards with locally growing grass cover, shading, trees and some water element can be substantially cooler than the ambient at the height of summer. Any type of shading by trees and presence of small water bodies were absent in the courtyards of all the three sample huts studied. Planting trees, bamboo groves and incorporating small lily-pools or a small water reservoir in the courtyard can be thought of as viable solutions to decrease the extreme high temperatures recorded in the courtyard during peak summer. Bamboo plants use transpiration to create their own microclimate, cooling a grove (or a house located in a grove) as much as 6 to 8 degree Celsius (Bansal et al. 2001).

The south side courtyard in the U-shaped dwelling unit can be temporarily shaded in summer by deciduous vines, creepers and Palmyra leaves spread over a framework on top constructed of split bamboo, twigs and small sticks. In none of the studied sample huts, has the courtyard being used as a source of ventilation air or has been used to induce stack effect and cross-ventilation as has been described by Roaf (2001) and Fathy (1973). Roaf (2001) suggests that corridors can be built between courtyard spaces that enable cross-ventilation. This can be incorporated in studied dwellings.

\section{Conclusions}

1. In the three courtyard - type dwellings studied the U-shaped dwelling unit with open courtyard (Sample Hut 3) records the least temperature amongst the three huts studied in summer. Summertime discomfort is the least in this dwelling both as per measured temperature records in peak summer as well as simulation results. Amongst the three courtyard-type dwellings studied, winter-time discomfort is least in square dwelling unit with central open courtyard (Sample-Hut1). However, since Sample Hut 1 exhibits the worst thermal performance amongst the three huts in summer, its use cannot be encouraged, as the hotter season is the dominant season in this type of tropical region.

2. Instead, the U-shaped dwelling unit (Sample Hut 3) can be used for year round inhabitation by improving its winter time performance by insulating mud walls and the clay-tiled roof. As per Soebarto, (2009), who carried out an analysis of indoor performance of houses using rammed earth walls, while 


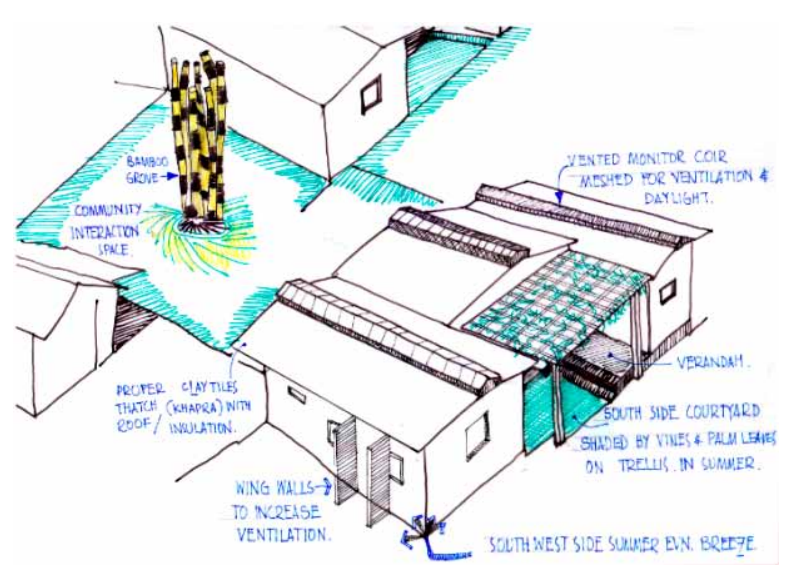

Fig. 23. Model dwelling unit: a modification of existing U-shaped dwelling

Source: drawn by author.

rammed earth walls indeed have high thermal mass, the thermal resistance of rammed earth alone is not great enough to retain heat in cold climate. Cold climate design dictates that rammed earth should be coupled with thermal insulation to attain higher thermal resistance. Her studies show that in summer, the un-insulated rammed earth houses have similar performance to the insulated rammed earth house; however, without using any heater, the un-insulated houses could be colder by as much as 5 degrees in winter. Simple measures like increasing insulation-level of mud walls with insertion of bamboo frame-work and application of cow-dung layer and insulating clay-tiled roof can decrease the total number of winter-time discomfort hours. This alongside the U-shaped dwelling's better thermal performance in summer would make it ideal for all year round.

3. As Figure 17 illustrates, the outside temperatures drop considerably from around mid night to $6 \mathrm{AM}$ in the morning in peak summer. However, due to high thermal mass of the $450 \mathrm{~mm}$ walls, the heat stored in the thermal mass of the $450 \mathrm{~mm}$ earth walls during daytime in radiated inside at night-time. This causes the inside temperatures to remain at a constant 35 degree Celsius even when outside temperatures have dropped to around 26-27 degree Celsius in peak of summer. To bring down the summer-time evening and night-time temperatures inside the U-shaped dwelling and decrease thermal capacity of walls, $200 \mathrm{~mm} / 300 \mathrm{~mm}$ mud walls can be proposed to be constructed in future new constructions instead of the presently used massive $450 \mathrm{~mm}$ thick walls. Also bamboo frame-work in the form of wattle and daub structure can be used instead of the presently used cob-walls being used, in which mud is lumped over each other.

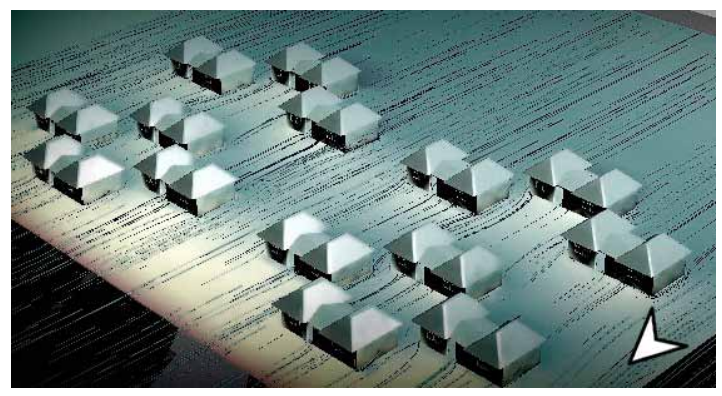

Fig. 24. Clustering of U-shaped dwelling units for availing of southern side summer-time evening breeze

4. Nocturnal ventilative cooling of thermal mass can be incorporated in the U-shaped dwelling by providing larger wire-meshed voids, keeping them covered during day-time to prevent direct heat gain, but allowing cool outside breeze to flow inside during evening and night-time. The voids should be wire-meshed to prevent insect and pest entry into dwelling.

5. The courtyards should be covered with a cover of locally growing grass, and vegetation or a small bamboo grove be placed to keep temperatures down in the courtyard.

6. The U-shaped dwelling unit (Sample Hut 3) can be developed as a model dwelling unit for year round habitation (Fig. 23) and arranged in proper clusters for availing of summer-time evening breeze as suggested by Olgyay, shown in Figure 8, earlier in this paper (Fig. 24). The southern courtyard can be covered with deciduous vines and creepers to protect from summer-time sunrays, but allow winter time sun rays in. This would encourage keeping alive the tradition of living as a community as well as provide thermal comfort round the year.

\section{References}

ASHRAE Standard 55-2004. American Society of Heating, Refrigeration, and Air-conditioning Engineers. International Standard.

Bansal, N. K.; Minke, G. 1988. Climatic zones and rural housing in India. Zentralbibliothek Publishers, 62-68, 132-149.

Bansal, A. K.; Jagadeesh, H. N.; Guruvareddy, H. 2001. Bamboo based housing system, New Building Materials and Construction World 7(6): 33-36.

Brager, G. S; De Dear, R. 2001. Climate, comfort \& natural ventilation: a new adaptive comfort standard for ASHRAE Standard 55, in Proceedings Moving Thermal Comfort Standards into the $21^{\text {st }}$ Century, 5-8 April 2001, Cumberland Lodge, Windsor, UK. 
CLIMATE CONSULTANT 6.0. [Software] Version 5.1. California, UCLA [online], [cited October 2012]. Available from Internet: www.aud.ucla.edu/energydesign-tools

Compare Infobase Ltd. 2014. mapsofindia.com [online], [cited 24 December 2014]. Available from Internet: http://www. mapsofindia.com

Cooper, I.; Dawson, B. 1998. Traditional buildings of India. London: Thames \& Hudson.

Das, N. 2006. Courtyards houses of Kolkata: bioclimatic, typological and socio-cultural study: Unpublished Masters of Architecture. Kansas State University, Manhattan.

Dhar, S. 1992. Regulating privacy: a comparison of the garo and santal cultures using the human relations area files: Unpublished Masters of Architecture. Kansas State University, Manhattan.

ECOTECT. 2011. ECOTECT for Windows. [Software] Version 2011. San Rafael, California, United States: Autodesk.

Fathy, H. 1973. Architecture for the poor: an experiment in rural Egypt Chicago. University of Chicago Press.

Gautam, A. 2008. Climate responsive vernacular architecture: Jharkhand, India: Masters Of Science Thesis. Department of Architecture, Kansas State University, Manhattan, Kansas, $1-40,54-59$ and $81-85$.

Koenigsberger, O. H.; Ingersoll, T. G.; Mayhew, A.; Szokolay, S. V. 1997. Manual of tropical housing and building. Orient Longman, 50, 221-227.

Nicol, J. F. 2001. Climate and thermal comfort in India, in A. Krishan, N. Baker, S. Yannas, S. V. Szokolay (Eds.). Climate responsive architecture: a design handbook for energy efficient buildings. New Delhi: Tata McGraw-Hill Publishing Company Limited, 59-67.

Olgyay, V. 1963. Design with climate- bioclimatic approach to architectural regionalism. 4th ed. New York: Van Nostrand Reinhold, 11-13, 72-74.

Reardon, C.; Downton, P. 2013. Passive design, design for climate [online], [cited 1 January 2015]. Available from Internet: http://www.yourhome.gov.au/technical

Roaf, S. C. 2001. Natural ventilation of buildings in India, in A. Krishan, N. Baker, S. Yannas, S. V. Szokolay (Eds.). Climate responsive architecture: a design handbook for energy efficient buildings. New Delhi: Tata McGraw-Hill Publishing Company Limited, 157.

Soebarto, V. 2009. Analysis of indoor performance of houses using rammed earth walls, in Eleventh International IBPSA Conference, 27-30 July 2009, Glasgow, Scotland.

Szokolay, S. V. 2004. Introduction to architectural science: the basis of sustainable design. Elsevier Science Ltd. (Architectural Press), 68.
SP 7:2005, National Building Code of India 2005. Bureau of Indian Standards, New Delhi 2005.

Yannas, S. 2001. Passive heating and cooling design strategies, in A. Krishan, N. Baker, S. Yannas, S. V. Szokolay (Eds.). Climate responsive architecture: a design handbook for energy efficient buildings. New Delhi: Tata McGraw-Hill Publishing Company Limited, 82-83.

\section{JANMEJOY GUPTA}

Dr Janmejoy Gupta is an Architect-Urban Planner with more than 12 years of industrial and teaching experience. Recently completed doctorate in Architecture. Presently Assistant Professor in Birla Institute of Technology, Mesra, Ranchi, India. Research areas are passive design strategies for thermal comfort in dwellings, Sustainability, and Urban Planning. Dr Gupta is an Indian Green Building Council Accredited Professional and has worked on a number of green building documentations.

\section{MANJARI CHAKRABORTY}

Dr Manjari Chakraborty, Professor, Architecture Department, Birla Institute of Technology, Mesra, Ranchi, India has three decades of simultaneous exposure in the profession, teaching, research, and administration in Architecture. She has qualifications in Architecture, Environment, Information Technology, and Research.

\section{ARNAB PAUL}

Arnab Paul is a LEED Green Associate and currently a Graduate Student in the Construction Management Program at Vanderbilt University, Nashville TN, USA. He is also working as a Project Management Intern with a local General Contractor named American Constructors Inc. Arnab completed his Bachelors in Architecture at BIT Mesra, Ranchi.

\section{VAMSI KORRAPATTI}

Vamsi Korrapati completed his Bachelors in Architecture at BIT Mesra, Ranchi. He is currently pursuing post graduation in project management from Australian National University, with a keen interest in green architecture. His research areas include sustainable architecture and Vernacular architecture. 